\title{
The Perception of Ageism, Generativity, and the Attainment of Developmental Tasks of Elderly Widowers and Widows in Bogor, West Java, Indonesia
}

\author{
Bona Intan Rahmaniah* \\ Department of Family and Consumer Sciences, \\ Faculty of Human Ecology, \\ Bogor Agricultural University
}

\author{
Diah Krisnatuti \\ Department of Family and Consumer Sciences, \\ Faculty of Human Ecology, \\ Bogor Agricultural University
}

*Corresponding author: bonaintan23@gmail.com

\begin{abstract}
In every stage of human lives as well as later adulthood (elderly) stage, there are developmental tasks to be attained and it demands the elderly to adapt to various changes both from the internal and external environments. The aim of this research was to analyze the influence of ageism perceived by elderly and generativity on the developmental tasks of elderly widowers and widows. The research was conducted in Empang Village, South Bogor SubDistrict and West Cilendek Village, West Bogor Sub-District, Bogor City, West Java, Indonesia. As many as 60 people were involved as participants, consisted of 30 elderly widowers and 30 elderly widows which were chosen by snowball techniques. The result showed that there was no significant difference in the developmental task of elderly widower and widow. The category of perception of ageism was low while of generativity and developmental task was moderate. There were significant positive influences of the length of education and generativity on developmental tasks of elderly widower and widow.
\end{abstract}

Keywords: developmental task, elderly widow, elderly widower, generativity, perception of ageism

\begin{abstract}
Abstrak. Pada setiap tahap kehidupan manusia termasuk tahap usia lanjut (lansia) terdapat tugas perkembangan yang harus diselesaikan dan menuntut lansia untuk beradaptasi dengan berbagai perubahan baik dari dalam diri sendiri maupun dari lingkungan sosial. Penelitian ini bertujuan untuk menganalisis pengaruh persepsi ageism dan generativitas terhadap tugas perkembangan lansia duda dan janda. Desain penelitian yang digunakan adalah cross-sectional study. Penelitian dilakukan di Kota Bogor tepatnya di Kelurahan Empang, Kecamatan Bogor Selatan dan Kelurahan Cilendek Barat, Kecamatan Bogor Barat. Sebanyak 60 orang dilibatkan sebagai contoh penelitian, terdiri dari 30 orang lansia duda dan 30 orang lansia janda yang dipilih dengan teknik snow-ball. Hasil penelitian menunjukkan tidak terdapat perbedaan nyata skor pencapaian tugas perkembangan lansia duda dan janda. Persepsi ageism berada pada kategori rendah sedangkan generatvitas dan tugas perkembangan pada kategori sedang. Terdapat hubungan dan pengaruh positif signifikan lama pendidikan dan generativitas terhadap tugas perkembangan lansia duda dan janda.
\end{abstract}

Kata kunci: generativitas, lansia duda, lansia janda, persepsi ageism, tugas perkembangan 


\section{Introduction}

The successful development in every aspect of lives has increased life expectancy that increases the population of elderly as well (Rahardjo et al., 2009). According to the Statistics Indonesia (2015), the life expectancy of Indonesian people in 2010-2015 has reached around 70 years old. It is estimated that by the year 2025, the percentage of Indonesian elderly will be 13.2 percent and it will create the inverted population pyramid by the year 2035 (Ananta, 2012; Bappenas, 2014). This issue is challenging, considering that the elderly is a non-productive group that can be an additional burden for the country and productive-aged group.

Based on The Act of Republic of Indonesia Number 13 of 1998 concerning Health, the elderly is an individual over 60 years old. There is a definitive shifting of elderly agreed by developed countries that is 65 years old, but United Nations remain to agree over 60 years old as the qualification of elderly (WHO, 2015). Elderly is characterized by aging that is a decline, infirmity, susceptibility to illness and environmental changes, loss of mobility and dexterity, and physiological changes related to age (Sudoyo et al., 2009).

Along with the decreasing due to aging, the elderly faces numerous changes that force them to adapt, such as changes in employment status (starting to get the pension) and in marital status (starting to be widower and widow) which is listed in the developmental task of elderly (Hurlock, 2009). According to Havighurst (1972), in every stage of human lives, there are developmental tasks to be attained which are the tasks that arise in social context during their lives. The developmental task of elderly by Havighurst (Hurlock, 2009), namely: (1) adjusting to the decrease in physical strength and health; (2) adjusting to retirement and reduced income; (3) adjusting to death of a spouse; (4) establishing an explicit affiliation with one's age group; (5) establishing satisfactory physical living arrangement; and (6) meeting social and civil obligations.

As the group of people in the last period of their lives, the elderly is surely expected to live well and be able to attain developmental tasks. But, an elderly often receives discrimination, stereotype, and negative viewpoint from the younger-aged group that is called by Butler as ageism (Palmore, 2001). As a result, elderly will assume themselves as a social burden and develop a strong sense of "waiting for death" while gerontophobia, that is a fear of getting old, will be sensed by younger people because of negative stereotypes toward elderly (Okoye and Obiketze, 2005). According to Sanchez et al. (2009), negative age stereotype influence one's perception and his involvement in society as well as physical activity. Alcock et al. (2011) also confirmed that negative stereotype caused the elderly being marginalized in society and social exclusion. As Hurlock (2009) and Erikson (1968) stated that social environment influences developmental task attainment, thus, the perception of ageism experienced by elderly in this study is aimed to represent the social challenge faced by elderly.

Meanwhile, the accomplished developmental task in a particular stage will determine its attainment in the next stage (Havighurst, 1972). One of the subjects related directly to the elderly stage is the developmental task of middle adulthood. As Havighurst (1972) stated that middle adulthood (age 30-60) is characterized by their influence on society, and in turn, the society demands social and civic responsibilities. This study aims to emphasize the social responsibility, which by the Erikson's Psychosocial Developmental Theory middle adulthood is characterized by generativity versus stagnant phase (Erikson, 1963). The successful in middle adulthood stage will 
lead to generativity which is defined as the ability of an individual to direct and guide future generations in reaching happiness (Papalia, Old, and Feldman, 2007).

Generativity is expected to contribute to successful aging (Huta and Zuroff, 2007; Vaillant, 2004). It is seen as the output of developmental task attainment of elderly because according to Baltes and Baltes (1990), successful aging is defined as the resilience of people who succeed in achieving a positive balance between gains and losses during aging.

According to the explanation above, a study of developmental task attainment of the elderly becomes important concerning to the fact that the number of elderly will increase along with the challenge faced by the elderly both from the social environment and themselves. Besides, the study of developmental task attainment of elderly is still rare and limited to the particular indicators of the developmental task by Havighurst. Therefore, the aim of this study was: (1) to identify the characteristics of perception of ageism, generativity, and developmental task and to compare the difference of each variable between elderly widower and widow; and (2) to analyze the factors that predict developmental task attainment of elderly widower and widow.

\section{Method}

\section{Participants}

The population of this study was elderly aged 60 or above living in Bogor, West Java, Indonesia. The study was located in Empang Village, South Bogor Sub-District and West Cilendek Village, East Bogor Sub-District. Bogor was chosen purposively as the research location as it is one of the cities in West Java with the highest number of elderly people (about 6\%) (Statistics Indonesia, 2012) and the two sub-districts are the highest population area of elderly in Bogor. Based on data from Integrated Data Base for Social Protection Program 2012, the population of elderly in West Bogor SubDistrict was 41.831 people and South Bogor Sub-District was 10.749 people. Thus, the sample was 60 elderly people, consisted of 30 elderly widowers and 30 elderly widows. Due to the data limitation of marital status of the elderly in these areas, the sample was chosen by snowball technique.

\section{Measures}

The data of sample characteristics were collected to identify the demographics of the sample in this study. The demographic variables were age, marital status, length of education, employment status, income, number of children, number of family member in a household, and number of health complaint which were fully openquestioned.

The dependent variable of this study was developmental task attainment of the elderly. The data were obtained using a questionnaire developed independently based on the Theory of Developmental Task of Elderly by Havihghurst. There were 16 items divided into six indicators: adjusting to decreasing physical strength and health (3 items), adjusting to retirement and reduced income ( 7 items), adjusting to death of a spouse (4 items), establishing an explicit affiliation with one's age group (3 items), establishing satisfactory physical living arrangement (1 item), and meeting social and civil obligations (3 items). All items were rated on a 5-point scale (1=strongly disagree; 
$2=$ disagree; $3=$ =neutral; $4=$ agree; $5=$ strongly agree) with the reliability value of 0.689 . The obtained score of this variable ranged from 16 to 80 .

The perception of ageism was measured using a questionnaire that was adapted and modified based on an instrument developed by Palmore (2000) titled Ageism Instrument. There were 16 items describing negative statements of perception of ageism experienced by elderly. All items were rated on a 3 -point scale $(0=$ never; $1=$ rarely; $2=$ often) and the reliability value of 0.685 . The obtained score ranged from 0 to 32 . Meanwhile, generativity was measured using a questionnaire that was adapted and modified based on McAdams and de St. Aubin's instrument (1992) titled Loyola Generativity Scale and Hapsah's (2010). The questionnaire consisted of 20 items rated on a 5-point scale (1=strongly disagree; $2=$ disagree; $3=$ neutral; 4=agree; 5=strongly agree) with the reliability value of 0.811 . The obtained score ranged from 20 to 100 .

The obtained scores in each variable (perception of ageism, generativity, and developmental tasks) were summed to create an index score as the following formula:

$$
\text { Index }=\frac{\text { Obtained score }- \text { minimum score }}{\text { maximum score }- \text { minimum score }} \times 100
$$

The transformation into index score is aimed to obtain the equal unit which will be comparable among variables (Puspitawati and Herawati, 2013). It would then be projected into three different categories: low $(<60)$, moderate $(60-80)$, and high $(>80)$. The categorization for main variables was used to provide descriptive information regarding the sample without any intention to oversimplify the interpretation of the attainments.

\section{Analysis}

Descriptive analysis used to describe the sample characteristics, the perception of ageism, generativity, and developmental tasks attainment were presented by frequency, mean, maximum, minimum, and deviation standard. Inferential analysis consisted of independent sample t-test and multiple linear regression analysis. The independent sample t-test was used to analyze the difference of each variable by examining mean differences by marital status. Meanwhile, the multiple linear regression analysis was used to predict the influence of independent variables on dependent variable. The multiple linear regression model is as follows:

$$
Y_{1}=\alpha+\beta_{1} X_{1}+\beta_{2} X_{2}+\beta_{3} X_{3}+\beta_{4} X_{4}+\beta_{5} X_{5}+\beta_{6} X_{6}+\beta_{7} X_{7}+\beta_{8} X_{8}+\beta_{9} X_{9}+\beta_{10} X_{10}+\varepsilon
$$

Where:

$\mathrm{Y}=$ developmental task; $\alpha=$ regression constant; $\beta_{1}-\beta_{10}=$ regression coefficient; $X_{1}=$ age; $\mathrm{X}_{2}=$ marital status; $\mathrm{X}_{3}=$ length of education; $\mathrm{X}_{4}=$ employment status; $\mathrm{X}_{5}=$ income; $X_{6}=$ number of health complaint; $X_{7}=$ number of child; $X_{8}=$ number of family member in a household; $\mathrm{X}_{9}=$ perception of ageism; $\mathrm{X}_{10}=$ generativity; $\varepsilon=$ error.

\section{Results}

\section{Demographic Characteristic of the Sample}

The result showed that the mean age of elderly widower was 72 years old while of elderly widow was 70 years old. The length of education of the elderly widower on average was eight years (equivalent to second year of junior high school) and the 
average of elderly widow was five years (equivalent to unfinished of elementary school). The average monthly income of elderly widower was Rp2.341.667 while of elderly widow was Rp823.333. Both elderly widower and widow got one health complaint. The types of health complaint suffered by the elderly were diabetes, heart problems, cataracts, lung disorders, high blood pressure, urinary tract, prostate, hernia, kidney disorders, gout, and cholesterol. Most elderly in this study (81.7\%) was not employed and/or never had employment (household wives). Meanwhile, it was found that the proportion of employed elderly widower (23.3\%) was higher than the employed elderly widow (13.3\%). Nearly all of the employed elderly in this study were an entrepreneur.

\section{Perception of Ageism}

Table 1 shows that all samples in this study perceive ageism in the low category. The average attainment of ageism experienced by both elderly groups was low that was below five percent. Meanwhile, the result of t-test for equality of mean showed that there was no significant difference in the mean score between elderly widowers and widows.

Table 1 Distribution of the sample by perception of ageism category and marital status

\begin{tabular}{lcccccc}
\hline Perception of ageism & \multicolumn{2}{c}{ Widower } & \multicolumn{2}{c}{ Widow } & \multicolumn{2}{c}{ Total } \\
\cline { 2 - 7 } & $\mathrm{n}$ & $\%$ & $\mathrm{n}$ & $\%$ & $\mathrm{n}$ & $\%$ \\
\hline Low $(<60)$ & 30 & 100.0 & 30 & 100.0 & 60 & 100.0 \\
Moderate $(60-80)$ & 0 & 0.0 & 0 & 0.0 & 0 & 0.0 \\
High $(>80)$ & 0 & 0.0 & 0 & 0.0 & 0 & 0.0 \\
\hline Total & 30 & 100.0 & 30 & 100.0 & 60 & 100.0 \\
Mean \pm SD & \multicolumn{2}{c}{$3.1 \pm 3.571$} & \multicolumn{2}{c}{$2.1 \pm 2.097$} & & \\
p-value & \multicolumn{7}{c}{0.223} & \\
\hline
\end{tabular}

\section{Generativity}

In general, half of the sample (50\%) attain the moderate level of generativity as shown in Table 2. More than half of the proportion of elderly widowers $(56.7 \%)$ attained a moderate level of generativity while less than a half was attained by the elderly widows $(43.3 \%)$. Otherwise, the low category of generativity was attained more by elderly widows than elderly widowers. Meanwhile, the high level of generativity is attained only by nearly one-third of the sample. The mean score of elderly widowers is higher than elderly widows, but it is not significantly different.

Table 2 Distribution of the sample by generativity category and marital status

\begin{tabular}{lcccccc}
\hline Generativity & \multicolumn{2}{c}{ Widower } & \multicolumn{2}{c}{ Widow } & \multicolumn{2}{c}{ Total } \\
\cline { 2 - 7 } & $\mathrm{n}$ & $\%$ & $\mathrm{n}$ & $\%$ & $\mathrm{n}$ & $\%$ \\
\hline Low $(<60)$ & 4 & 13.3 & 7 & 23.3 & 11 & 18.3 \\
Moderate $(60-80)$ & 17 & 56.7 & 13 & 43.3 & 30 & 50.0 \\
High $(>80)$ & 9 & 30.0 & 10 & 33.3 & 19 & 31.7 \\
\hline Total & 30 & 100.0 & 30 & 100.0 & 60 & 100.0 \\
Mean \pm SD & $74.9 \pm 13.173$ & $73.2 \pm 13.676$ & & \\
p-value & \multicolumn{2}{c}{0.633} & & & & \\
\hline
\end{tabular}

\section{Developmental Task}

In general, developmental task of elderly widowers and elderly widows is in the moderate level that was attained by nearly two-third of the sample (63.3\%) (Table 3). 
Nearly a half proportion of elderly widows (40\%) attained low level while more than three-fourth of the elderly widowers $(80 \%)$ attained moderate and high level. The result of t-test for equality of mean showed that the mean score of elderly widowers $(75.5 \%)$ was higher than elderly widows (72.2\%), but the difference was not significant.

Table 3 Distribution of the sample by developmental task category and marital status

\begin{tabular}{lcccccc}
\hline Developmental task & \multicolumn{2}{c}{ Widower } & \multicolumn{2}{c}{ Widow } & \multicolumn{2}{c}{ Total } \\
\cline { 2 - 7 } & $\mathrm{n}$ & $\%$ & $\mathrm{n}$ & $\%$ & $\mathrm{n}$ & $\%$ \\
\hline Low $(<60)$ & 6 & 20.0 & 12 & 40.0 & 18 & 30.0 \\
Moderate $(60-80)$ & 21 & 70.0 & 17 & 56.7 & 38 & 63.3 \\
High $(>80)$ & 3 & 10.0 & 1 & 3.3 & 4 & 6.7 \\
\hline Total & 30 & 100.0 & 30 & 100.0 & 60 & 100.0 \\
Mean \pm SD & \multicolumn{2}{c}{$75.7 \pm 9.963$} & $72.2 \pm 10.893$ & & \\
p-value & \multicolumn{2}{c}{0.208} & & & & \\
\hline
\end{tabular}

The highest indicator of developmental tasks of both elderly groups that is shown in Table 4 is meeting with social and civil obligations. Conversely, the indicator of adjusting to physical strength and health was the lowest indicator attainment. In comparison with other elderly groups, both elderly widowers and widows have the highest score in meeting with social and civil obligations. On the other hand, the lowest score of developmental task indicator of elderly widowers was adjusting to decreasing physical strength and health while elderly widows attained the lowest score in adjusting to retirement and reduced income.

Table 4 Percentage of mean score of developmental task indicator

\begin{tabular}{|c|c|c|c|}
\hline Developmental task indicator & Widower & Widow & Total \\
\hline $\begin{array}{l}\text { Adjusting to decreasing physical strength and } \\
\text { health }\end{array}$ & 50.0 & 52.2 & 51.1 \\
\hline Adjusting to retirement and reduced income & 57.7 & 47.5 & 52.6 \\
\hline Adjusting to death of a spouse & 66.7 & 71.0 & 68.8 \\
\hline $\begin{array}{l}\text { Establishing an explicit affiliation with one's age } \\
\text { group }\end{array}$ & 74.4 & 71.7 & 73.1 \\
\hline $\begin{array}{l}\text { Establishing } \\
\text { arrangement }\end{array}$ satisfactory physical living & 80.0 & 70.0 & 75.0 \\
\hline Meeting social and civil obligations & 80.8 & 74.2 & 77.5 \\
\hline
\end{tabular}

\section{The Factors That Predict Developmental Task}

The result of multiple linear regression analysis showed that the length of education $(p=0.007 ; \beta=0.360)$ and generativity $(p=0.018 ; \beta=0.303)$ were the significant predictors of developmental task attainment of elderly (Table 6). It indicates that elderly who had higher education level and higher generativity level were more likely to attain higher developmental task. It was also found that 30.1 percent of the variance in the measure of the developmental task could be predicted by the measure of independent variables while 69.9 percent was predicted by other factors that were not analyzed in this study.

The multiple linear regression formula of this study is as follows:

$$
\begin{aligned}
Y_{1}= & 31.736+0.817 X_{1}+1.127 X_{2}+1.045 X_{3}+3.858 X_{4}+(3.681 \mathrm{E}-7) X_{5}+1.535 X_{6}+ \\
& 0.524 X_{7}+0.049 X_{8}-0.195 X_{9}+0.275 X_{10}+\varepsilon
\end{aligned}
$$

As the significant predictor, the length of education predicted an increasing of developmental task attainment score as big as 1.045 points. Meanwhile, generativity 
score was likely to alter developmental task attainment score positively as big as 0.275 points.

Table 5 Multiple linear regression analysis of characteristics, perception of ageism, and generativity on developmental task

\begin{tabular}{|c|c|c|c|}
\hline Variable & $\begin{array}{l}\text { Unstandardized } \\
\text { coefficient (B) }\end{array}$ & $\begin{array}{c}\text { Standardized } \\
\text { coefficient }(\beta)\end{array}$ & Significance \\
\hline Constant & 31.736 & & 0.003 \\
\hline Age (year) & 0.817 & 0.033 & 0.266 \\
\hline Marital status $(0=$ widow; $1=$ widower $)$ & 1.127 & 0.047 & 0.697 \\
\hline Length of education (year) & 1.045 & 0.360 & $0.007 * *$ \\
\hline $\begin{array}{l}\text { Employment status }(0=\text { unemployed; } \\
1=\text { employed })\end{array}$ & 3.858 & 0.125 & 0.310 \\
\hline Income (Rp) & 3.681E-7 & 0.185 & 0.117 \\
\hline Health complaint (unit) & 1.535 & 0.130 & 0.259 \\
\hline Number of child (person) & 0.524 & 0.125 & 0.329 \\
\hline $\begin{array}{l}\text { Number of family member in household } \\
\text { (person) }\end{array}$ & 0.049 & 0.010 & 0.936 \\
\hline Perception of ageism (index score) & -0.195 & -0.146 & 0.212 \\
\hline Generativity (index score) & 0.275 & 0.303 & $0.018 *$ \\
\hline Adjusted R square & & 0.301 & \\
\hline $\mathrm{F}$ & & 3.542 & \\
\hline Sig & & 0.001 & \\
\hline
\end{tabular}

Note. $(* *)$ significant at $\mathrm{p}<0.01 ;(*)$ significant at $\mathrm{p}<0.05$

\section{Discussions}

The results of this study showed that the elderly widowers took a longer time than the elderly widows in education that was 8 years (equivalent to the second year of junior high school). This result goes along with the statement of Kurniasari and Leonardi (2013) that the length of education of elderly men is higher than the elderly women due to education for elderly men are being more prioritized. In fact, the general level of education of elderly in Indonesia is not so good that education is not seen as an important issue (Setiabudhi, 2005). Along with education is the skill of elderly in which the elderly widowers $(80 \%)$ revealed that they had important skills to teach to others more than the elderly widows $(53.3 \%)$.

The elderly widowers had the average of monthly income higher than the elderly widows. the result of this study also showed that the total number of working elderly widowers were more than the elderly widows. More than one-third of elderly widowers (36.7\%) stated that they had an economic activity while there was only 23.3 percent of elderly widows had the same activity. It might be caused by the economic condition which motivated the elderly men as the main breadwinner to keep working and/or the physical condition that possibly made them work (Affandi, 2009).

Meanwhile, Palmore' study (2001) showed that more than a half of the sample $(n=84)$ had ever received ageism more than once. Conversely, all sample of this study attained the perception of ageism score below five percent which indicated that there was no tendency to receive ageism more than once. According to the interview, the elderly in this study stated that there was behavior difference received from their society as older persons, but it was not a matter, even more, an obstacle to socializing. As Palmore (2001) stated that the elderly tend to not perceive particular behaviors as an 
ageism. The elderly in this study perceived ageism as a common thing, the way younger people cared about them, and even a joke only.

This finding shows that perception of ageism is not an issue at least in the location of this study and it does not significantly predict developmental task attainment of elderly widower and widow. Mujtaba et. al (2004) stated that Asian and Middle Eastern cultures hold politeness and respect older persons. The difference of study location, as well as distinct cultures and characteristics of the sample, explain the difference of the result between this study and prior study that was held in Western society. Therefore, the result does not support the hypothesis that perception of ageism, the representative of social environment, influences developmental task attainment (Hurlock, 2009; Erikson, 1968).

The elderly relatively attained low generativity in LGS instrument (Schoklitsch and Baumann, 2012). Strasser (2008) found that individual without a spouse, divorced, and widow/widower did not have a good level of generativity, particularly compared to a married individual or the one with a spouse. James and Zarret (2005) stated that generativity possibly decreased along with intimacy loss. This explains the condition of a low-level generativity reached by elderly widower and widow in this study. This study also confirmed the prior finding stating that elderly widower and widow tend to not have a good level of generativity.

The result of this study revealed that nearly two-third of the elderly $(63.3 \%)$ attained the moderate level of developmental task and there was 30 percent of elderly in the low level. It indicates that developmental task attainment of the elderly is commonly not good enough. It is about one-third of the elderly showed a bad ability in adjusting to retirement (Braithwaite and Gibson, 1987; Braithwaite, Gibson, and Bosly-Craft, 1986). In line with the finding, one-third of the elderly in this study also showed a low attainment in adjusting to retirement and reduced income. The adjustment done by the elderly widows was not as good as what the elderly widowers did. It is not wondering because more than two-third of the elderly widows in this study was not employed and did not have any economic activity as financial support.

The elderly widows adjusted to death of a spouse better than the elderly widowers. This finding is in line with the study stated that the elderly men were more depressed over losing spouse compared to the elderly women (Lee et al., 2001). The elderly in this study is considered socially active, join the religious activity. According to the interview, the elderly widows tend to not socialize because they are worried about involving in negative things such as talking about the badness and weaknesses of others. It was revealed by elderly widows who was worried about socializing especially because of their marital status. In line with the study of Chen et al. (2011), on average, elderly widows in this study lived with 4 family members and more than a half of the sample said that they were satisfied with the living arrangement.

This study proved that developmental task of elderly is predicted by generativity as the developmental task of the previous stage, indicating that the elderly who have higher generativity level is more likely to attain higher developmental task score. This finding supports the hypothesis that successful developmental task attainment in a particular stage will determine developmental task attainment in the next stage (Havighurst, 1972). Based on the previous study concerning the relationship between generativity and successful aging, this study proved that the low level of generativity had an implication on developmental task attainment of elderly in the same level. It could be stated that the term of successful aging could not be attached to elderly in this 
study. The successful aging is seen as an output of developmental task attainment of elderly because Baltes and Baltes (1990) defines it as an individual's resiliency who succeed in balancing between gains and losses during aging.

The length of education was positively associated with developmental task attainment of elderly. It indicates that the low education level of elderly had a higher probability of lower developmental task attainment. The finding of Meeks and Maurrell (2001) showed that the length of education was correlated with successful aging because it is believed that an educated person would develop a better method for solving problems and coping with changes. Besides, education is a determinant of individual social economic status (Syafrudin and Mariam, 2010). High education level has the implication on high social economic status. Therefore, in this case, an individual could be able to attain developmental tasks well, or vice versa. On the other hand, low education level disabled the elderly to develop an ability to attain developmental task including facing many challenges and changes in this stage. Thus, the hypothesis that education level predicts developmental task attainment is supported by this result. Some other factors that can predict developmental task are the picture of body image, motivation, knowledge, personality, opportunity, guidance, family support, and creativity (Hurlock, 2009).

There are some limitations in this study. The main issue is the instrument used for each variable. The cultural differences as well as sample characteristic compared to prior study cause the instrument of perception of ageism less reliable although it has been modified. Future study needs a deeper review on the instrument so that it will be able to capture the real circumstances in the research location. The instrument reliability issue also occurs on the instrument of the developmental task. Meanwhile, generativity is better assessed using the latest instrument by Kotre which contains several forms of generativity. Future research of generativity on elderly is considered to differentiate generativity on midlife and present life (elderly) as the study of Schoklitsch and Baumann (2011) analyzed the difference between the two stage of lives.

\section{Conclusion and Recommendation}

\section{Conclusion}

The age of sample in this study is above 70 years old on average. The length of education of the elderly widower is equivalent to the second year of junior high school while the elderly widow is equivalent to elementary school. On average, monthly income of the elderly widower is three times higher than the elderly widow. More than a half of the sample is not employed. The highest proportion of the employed elderly is the elderly widower. The perception of ageism level of all samples is at low while the moderate level of generativity and of the developmental task. The elderly widower gains a higher mean score of ageism, generativity, and developmental task but the t-test for equality of means shows that there is no significant difference between the elderly widower and widow. The length of education and generativity positively influence developmental task attainment of elderly widower and widow. 


\section{Recommendation}

According to the results of this study, the elderly widower and widow are expected to increase their ability in attaining developmental task both at their stage and at the prior stage. The increment of education quality in Indonesia is also needed to help the increasing of individual attaining developmental task at every stage. Health care center for elderly integrated with economic or social activity is purposed to keep the elderly active and productive, and to avoid the sense of "waiting for death". As an effort of adjusting to physical strength and health decreased, the elderly needs to utilize the medical insurance either by the government or other parties, and/or another medical facilities to maintain their health regularly, consume supplement, and also doing a light exercise according to their physical condition. Meanwhile, further studies on ageism in Indonesia need deeper review especially in term of instrument used so that it will capture the reality within Indonesian society.

\section{Reference}

Affandi, M. (2009). Faktor-faktor yang mempengaruhi penduduk lanjut usia memilih untuk bekerja [Factors that affect the elderly 's decision to work]. Journal of Indonesia Applied Economics, 3(2), 99-110. Retrieved from http://jiae.ub.ac.id/index.php/jiae/article/view/131/100.

Ananta, A. (2012). Financing Indonesia's ageing population. In D. Singh, P. Thambipillai (Eds.), South East Asian affairs (pp. 135-149). Singapore: ISEAS.

Alcock, C. L., Camic, P. M., Barker, C., Haridi, C., \& Raven, R. (2011). Intergenerational practice in the community: A focused ethnographic evaluation. Journal of Community \& Applied Social Psychology, 21(5), 419-432. doi: 10.1002/casp.1084.

Baltes, P. B., \& Baltes, M. M. (1990). Psychological perspectives on successful aging: The model of selective optimization with compensation. In P. B. Baltes \& M. M. Baltes (Eds.), Successful aging: Perspectives from the behavioral sciences (pp. 1-34). New York: Cambridge University Press.

Braithwaite, V. A., \& Gibson, D. M. (1987). Adjustment to retirement: What we know and what we need to know. Ageing and Society, 7(1), 1-18. doi: 10.1017/SO144686X00012265.

Braithwaite, V. A., Gibson, D. M., \& Bosly-Craft, R. (1986). An exploratory study of poor adjustment styles among retirees. Social Science and Medicine, 23, 493-499. doi: 10.1016/0277-9536(86)90009-2.

Chen, S. M., Wang, S. H., \& Lin, P. S. (2011, July). The relationship between the living arrangement and life satisfaction of the elderly. Paper presented at Enhr Conference, Toulouse, France. Retrieved from http://www.enhr2011.com/sites/default/files/paper-Shumei\%20CHEN-WS15.pdf.

Erikson, E. H. (1963). Childhood and Society (2nd ed.). New York, NY: Norton.

Erikson, E. H. (1968). Identity: Youth and crisis. New York, NY: Norton.

Hapsah. (2010). Pengaruh terapi kelompok terapeutik terhadap perkembangan generativitas perempuan paruh baya di Kabupaten Pinrang tahun 2010 [The influence group therapy therapeutic on the development of generativity of middleaged woman in Pinrang 2010] (Master's thesis). Retrieved from http://lib.ui.ac.id/detail.jsp\&id=20282726\&lokasi=lokal. 
Havighurst, R. J. (1972). Developmental Tasks and Education (3rd ed.). New York, NY: David McKay.

Hurlock, E. B. (2009). Psikologi Perkembangan: Suatu Pendekatan Sepanjang Rentang Kehidupan [Developmental Psychology: A Life-Span Approach] (Istiwidayanti \& Doedjarwo, Trans.). Jakarta, Indonesia: Erlangga.

Huta, V., \& Zuroff, D. C. (2007). Examining mediators of the link between generativity and well-being. Journal of Adult Development, 14, 47-52. doi: 10.1007/s10804007-9030-7.

James, J. B., \& Zarrett, N. (2005). Ego integrity in the lives of older women: A followup of mothers from the Sears, Maccoby, and Levin (1951) patterns of child rearing study. Journal of Adult Development, 12(4), 155-167. doi: 10.1007/s10804-0057084-y.

Kurniasari, K., \& Leonardi, T. (2013). Kualitas perempuan lanjut usia yang melajang [The quality of single older women]. Jurnal Psikologi Pendidikan dan Perkembangan, 2(3), 152-159. Retrieved from http://journal.unair.ac.id/downloadfullpapers-jpppa9f22e5035full.pdf.

Lee, G. R., DeMaris, A., Bavin, S., Sullivan, R. (2001). Gender differences in the depressive effect of widowhood in later life. Journal of Gerontology: Social Sciences, 56B(1), S56-S61. doi: 10.1093/geronb/56.1.s56.

Maryam, R. S., Ekasari, M. F., Rosidawati, Jubaedi, A., \& Batubara, I. (2008). Mengenal Usia Lanjut dan Perawatannya [Recognizing the Elderly and the Maintenance]. Jakarta, Indonesia: Salemba Medika.

McAdams, D. P., \& de St. Aubin, E. (2012). A theory of generativity and its assessment through self-report, behavioral acts, and narrative themes in autobiography. Journal of Personality and Social Psychology, 62(6), 1003-1015. doi: 10.1037/00223514.62.6.1003.

Meeks, S., \& Murrell, S. A. (2001). Contribution of education to health and life satisfaction in older adults mediated by negative affect. Journal of Aging and Health, 13, 92-119.

Mujtaba, B. G., Hinds, R. M., \& Oskal, C. (2004). Cultural paradigms of age discrimination and unearned privileges. Journal of Business and Economics Research, 2(12), 31-44. Retrieved from http://www.cluteinstitute.com/ojs/index.php/JBER/article/view/2948/2996.

Okoye, U. O., \& Obikeze, D. S. (2005). Stereotypes and perceptions of the elderly by the youth in Nigeria: Implications for social policy. Journal of Applied Gerontology, 24(5), 439-452. doi: 10.1177/0733464805278648.

Palmore, E. (2001). The ageism survey: First findings. The Gerontologist, 41(5), 572575. doi: 10.1093/geront/41.5.572.

Papalia, D. E., Olds, S. W., \& Feldman, R. D. (2007). Human Development (10th ed.). New York, NY: McGraw-Hill.

Puspitawati, H., \& Herawati, T. (2013). Metode Penelitian Keluarga [Family Research Method]. Bogor, Indonesia: IPB Press.

Rahardjo, T. B. W., Hartono, T., Dewi, V. P., Hogervorst, E., \& Arifin, E. V. (2009). Facing the geriatric wave in Indonesia financial conditions and social support. In E. N. Arifin \& A. Ananta (Eds.), Older persons in Southeast Asia (pp. 272-298). Singapore: ISEAS.

Sánchez, P. C., Trianes, T. M. V., \& Blanca, M. M. J. (2009). Negative aging stereotypes and their relation with psychosocial variables in the elderly population. 
Archives of Gerontology and Geriatrics, 48(3), 385-390. doi: 10.1016/j.archger.2008.03.007

Schoklitsch, A., \& Baumann, U. (2011). Measuring generativity in older adults. GeroPsych, 24(1), 31-43. doi: 10.1024/1662-9647/a000030

Setiabudhi, T., \& Hardywinoto. (2005). Panduan Gerontologi Tinjauan dari Berbagai Aspek: Menjaga Keseimbangan Kualitas Hidup Para Lanjut Usia [Gerontology Guide Overview of Various Aspects: Balancing the Quality of Life of the Elderly]. Jakarta, Indoneisa: Gramedia Pustaka Utama.

State Ministry of National Development Planning. (2014). Bappenas dan BPS rancang proyeksi penduduk 2035 [Bappenas and Statistics Indonesia design and population projections 2035]. Retrieved from http://perpustakaan.bappenas.go.id/lontar/file?file=digital/120891-

$\% 5 \mathrm{~B} \_$Konten_\%5D-Bappenas-Hen0001.pdf.

Statistics Indonesia. (2015). Life Expectancy of Population on Selected Countries (years), 1995-2015. Retrieved from http://www.bps.go.id/linkTabelStatis/view/id/1517.

Strasser, M. (2008). Does Reaching Generativity Denote Lack of Depression Later in Life?. Illinois, IL: Proquest.

Sudoyo, A. W., Setiyohadi, B., Alwi, I., Simadibrata, M., \& Setiati, S. (2009). Buku Ajar Ilmu Penyakit Dalam [Textbook of Medicine]. (2nd vol., 5th ed.). Jakarta, Indonesia: Interna Publishing.

Sunarti, E. (2004). Mengasuh dengan Hati [Parenting with Heart]. Jakarta, Indonesia: PT Elex Media Komputindo.

Syafrudin, \& Mariam, N. (2010). Sosial Budaya Dasar Untuk Mahasiswa Kebidanan [Social and Cultural Basis For Midwifery Students]. Jakarta, Indonesia: Trans Info Media Jakarta.

Uhlendorff, U. (2004). The concept of developmental-tasks and its significance for education and social work. Social Work and Society, 2(1), 54-63. Retrieved from http://www.socwork.net/sws/article/view/240/415.

Vaillant, G. E. (2004). Positive aging. In P. A. Linley \& S. Joseph (Eds.), Positive Psychology in Practice. NJ: Wiley. doi: 10.1002/9780470939338.ch34.

Versey, H. S., \& Newton, N. J. (2013). Generativity and productive pursuits: pathways to successful aging in late midlife African American and White women. Journal of Adult Development, 20(2). doi: 10.1007/s10804-013-9170-х.

World Health Organization. (2015). Definition of an older or elderly person. Retrieved from http://www.who.int/healthinfo/survey/ageingdefnolder/en. 